\title{
Article \\ The Potential of Micromammals for the Stratigraphy and the Timing of Human Occupations at La Roche-à-Pierrot (Saint-Césaire, France)
}

\author{
Loïc Lebreton 1,*(D), Eugène Morin 2,3 ${ }^{(D}$, Brad Gravina ${ }^{3}$, Alexandre Michel ${ }^{3,4}$, François Bachellerie ${ }^{3,5}$, \\ Cédric Beauval $^{6}$, Damien Flas ${ }^{7,8}$, Véronique Laroulandie ${ }^{3} \mathbb{D}$, Josserand Marot ${ }^{9}$, Hélène Rougier ${ }^{10}(\mathbb{D})$, \\ Elise $\operatorname{Tartar}^{8}$, Dominique Todisco ${ }^{11}$ and Isabelle Crevecoeur ${ }^{3}$
}

check for updates

Citation: Lebreton, L.; Morin, E.; Gravina, B.; Michel, A.; Bachellerie, F.; Beauval, C.; Flas, D.; Laroulandie, V.; Marot, J.; Rougier, H.; et al. The Potential of Micromammals for the Stratigraphy and the Timing of Human Occupations at La

Roche-à-Pierrot (Saint-Césaire, France). Quaternary 2021, 4, 33. https://doi.org/10.3390/quat4040033

Academic Editors: Juan Rofes, Janine Ochoa and Emmanuelle Stoetzel

Received: 16 August 2021 Accepted: 12 October 2021 Published: 21 October 2021

Publisher's Note: MDPI stays neutral with regard to jurisdictional claims in published maps and institutional affiliations.

Copyright: (c) 2021 by the authors. Licensee MDPI, Basel, Switzerland. This article is an open access article distributed under the terms and conditions of the Creative Commons Attribution (CC BY) license (https:/ / creativecommons.org/licenses/by/ $4.0 /)$.
1 Histoire Naturelle de l'Homme Préhistorique (HNHP), UMR 7194, Département Homme et Environnement du Muséum National d'Histoire Naturelle, MNHN-CNRS-UPVD, Musée de l'Homme, 75000 Paris, France

2 Department of Anthropology, Trent University, DNA Block C, 2140 East Bank Drive,

Peterborough, ON K9J 7B8, Canada; eugenemorin@trentu.ca

3 PACEA, UMR 5199, CNRS, Université de Bordeaux, MC, B2, Allée Geoffroy Saint-Hilaire, CEDEX, 33615 Pessac, France; gravina.brad@gmail.com (B.G.); alex.michel10@laposte.net (A.M.); bachellerie.francois@gmail.com (F.B.); veronique.laroulandie@u-bordeaux.fr (V.L.); isabelle.crevecoeur@u-bordeaux.fr (I.C.)

4 Service Départemental de l'Archéologie, Conseil Départemental de la Dordogne, 2 Rue Paul Louis Courrier, CS11200, CEDEX, 24019 Périgueux, France

5 Archéologie Alsace, 11 Rue Jean-François Champollion, 67600 Sélestat, France

6 Archéosphère, 10 Rue de la Rhode, 11500 Quillan, France; c.beauval@archeosphere.com

7 Service de Préhistoire, Université de Liège, Place du 20-Août 7, 4000 Liège, Belgium; damienflas@yahoo.com

8 TRACES, UMR 5608, CNRS, Université Toulouse Jean Jaurès, Maison de la Recherche, 5 Allées Antonio Machado, CEDEX 9, 31058 Toulouse, France; elise.tartar@cnrs.fr

9 Service Départemental de l'Archéologie, Conseil Départemental de Charente-Maritime, Caserne Brémond d'Ars, Petite Rue du Séminaire, 17100 Saintes, France; marot.josserand@gmail.com

10 Department of Anthropology, California State University Northridge, 18111 Nordhoff St., Northridge, CA 91330-8244, USA; helene.rougier@csun.edu

11 IDEES, UMR 6266, Université de Rouen, 17 Rue Lavoisier, CEDEX, 76821 Mont Saint Aignan, France; dominique.todisco@univ-rouen.fr

* Correspondence: loicleb@hotmail.com

\begin{abstract}
As micromammals are highly sensitive to changes in their habitat, variations in species representation are often used to reconstruct local environmental conditions. However, taphonomic aspects of micromammals are often overlooked, despite the fact that they can provide important information for our understanding of archaeological sites. La Roche-à-Pierrot, Saint-Césaire, is a major archaeological site for our understanding of the Middle-to-Upper Palaeolithic transition in Western Europe. Clearly documenting site formation processes, the post-depositional reworking of deposits and the sequence of human occupations is fundamental for providing a secure archaeostratigraphic context of the site. The exceptionally large accumulation of micromammals from recently excavated stratigraphic units at the site makes it possible to track variations in the density of micromammals across the stratigraphic sequence. The taphonomic analysis of micromammals demonstrates these variations are not related to a change in the main accumulation agent or post-depositional phenomena. A negative correlation between small mammal remains and archaeological material suggests that peaks in micromammal densities can potentially be correlated with periods when the site was abandoned or when human occupation was less intense, and therefore provide new data for interpreting the Saint-Césaire stratigraphic sequence.
\end{abstract}

Keywords: micromammals; taphonomy; density analysis; Late Pleistocene 


\section{Introduction}

The analysis of micromammals has primarily focused on palaeoenvironmental reconstructions, given their high potential for recording climatic fluctuations [1-5]. Most taphonomic analyses of micromammal fossil accumulations tend to concentrate on identifying biases in the representation of species in fossil assemblages and living communities. The frequent documentation of such biases is due to the fact that micromammal accumulations typically result from the feeding practices of one or more predators and post-depositional phenomena, including the fossilisation process. These biases could affect both palaeocommunities and skeletal part representation, as well as distorting the palaeoecological signal [6-10]. Taphonomic studies of small mammals generally focus on the identification of the principal accumulation agent and the characterisation of post-depositional processes [11]. The relationship between micromammals (primarily small rodents and insectivores) and the various categories of archaeological material recovered from a given site has received little attention. Apart from the Chalcolithic site of El Portalón [12], the Upper Palaeolithic sites of Peyrazet [13,14] and Taillis des Coteaux [15] and the Middle Palaeolithic site of Les Pradelles [13], relatively few studies have focused on the correlation between micromammals and archaeological material.

Here we test a simple hypothesis: as raptors are highly sensitive to disturbances in their habitat $[16,17]$, human activity on an archaeological site should be negatively correlated with their presence, and consequently, with the quantity of micromammal accumulated by these predators. As such, tracking shifting densities in micromammal remains can provide complementary data for assessing the timing of human occupations at a given site.

La Roche-à-Pierrot, Saint-Césaire is a key site for understanding the Middle-to-Upper Palaeolithic transition and is perhaps best known for Neandertal remains recovered from a level attributed to the Châtelperronian during excavations [18]. However, a recent technotypological and taphonomic revision of the lithic material from this level produced no reliable evidence for a Neandertal-Châtelperronian association at the site [19]. A previous analysis of the Saint-Césaire macrofaunal remains documented a negative correlation between the relative abundance of carnivore remains and carnivore damage on bone surfaces. When considered alongside additional evidence for human occupation, such as the proportion of burnt faunal remains, these correlations were interpreted as reflecting changes in the intensity of the site's occupation [20]. Here we use micromammal remains recovered during ongoing excavations at Saint-Césaire to further explore the timing and frequency of the human occupations at the site.

\section{Site Presentation}

The site of La Roche-à-Pierrot is a collapsed rockshelter located in southwestern France on the commune of Saint-Césaire (Figure 1A). Excavated by F. Lévêque between 1976 and 1987, the site yielded Neandertal remains and a complex Mousterian-ChâtelperronianAurignacian cultural sequence [21]. Marquet's [22] palaeoecological analysis of rodent remains from Lévêque's excavations highlighted a cold phase reflected in the presence of Lasiopodomys gregalis and Microtus oeconomus. The large fauna mainly comprises reindeer, bison and horses, with carnivores (spotted hyena, wolf and fox) only sporadically present across the stratigraphic sequence. The presence of small taxa, such as lagomorphs and birds, were interpreted as primarily reflecting background accumulations [20]. 


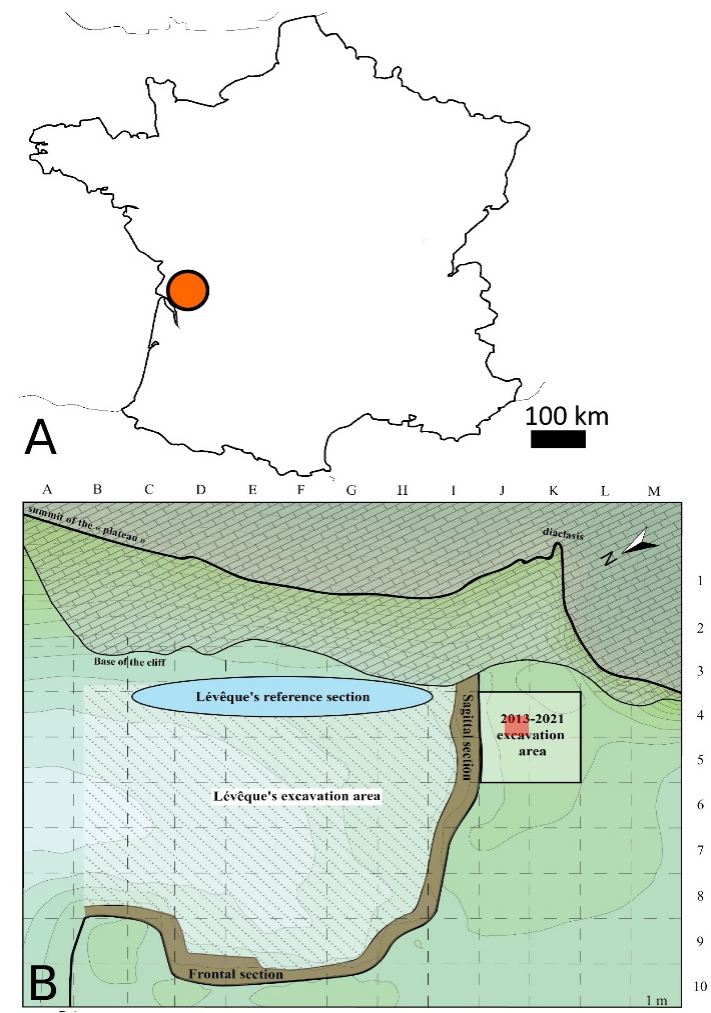

Sagittal section KLM-J4 III (a)

Lévêque's SU

layers

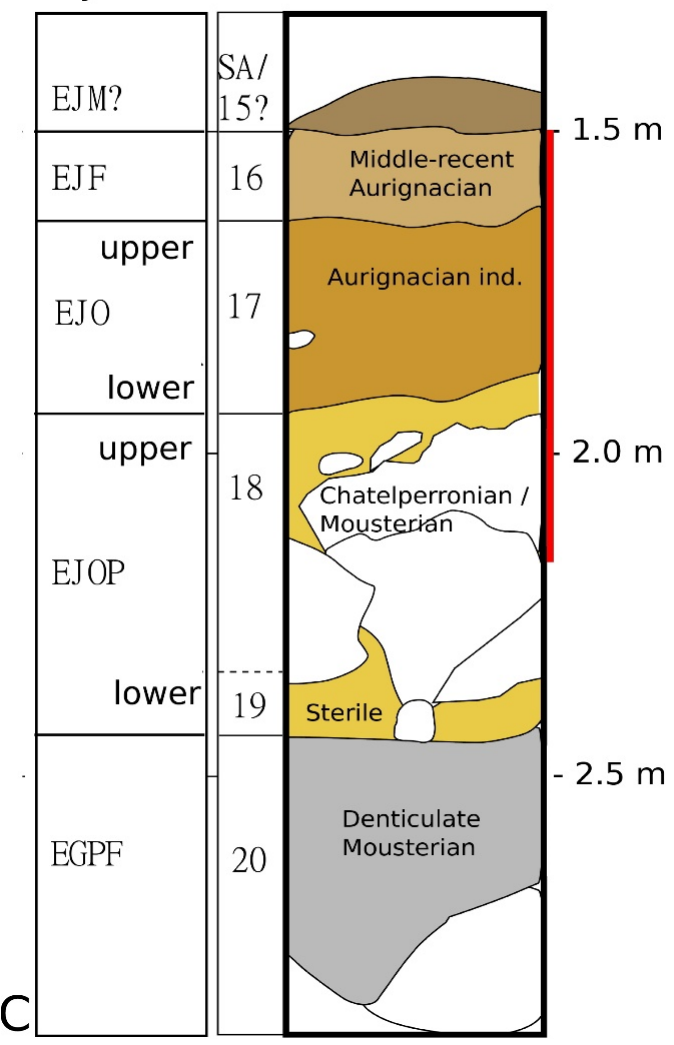

Figure 1. (A) Location of La Roche-à-Pierrot, Saint-Césaire (orange circle); (B) topographic plan with the excavation grid: the square on the right corresponds to the currently excavated area and the red 
inset to the study area; $(\mathrm{C})$ stratigraphic log with the correspondence between Lévêque's layers (EJF, EJO, EJOP, EGPF) and the stratigraphic units (SU) identified during the new excavations. The stratigraphic portion studied in the present paper is represented in red.

Excavations at Saint-Césaire were resumed by F. Bachellerie and E. Morin in 2013-2014, and by I. Crevecoeur since 2015. The goal of these new excavations is to produce a better understanding of the site's stratigraphic sequence and associated formation processes [23]. As it was impossible to establish a direct stratigraphic link between the site's sections, stratigraphic units (SU) were-to avoid confusion-numbered from 15 to 19 in the area that was the primary focus of the new excavations. Here, we focus on this series of newly excavated stratigraphic units. The stratigraphic sequence in this area of the site comprises SU 15 to the top of SU 19. Directly underlying a humic deposit referred to as SU 15-humus, the $10 \mathrm{~cm}$ thick SU 15 is characterised by dark brown clayey sediments with some evidence for post-depositional reworking. The limited number of lithic artefacts from SU 15 makes it impossible to establish a reliable archaeological attribution for this unit. The $20 \mathrm{~cm}$ thick SU 16 is characterised by brown clayey sediment with heterometric limestone fragments and contains a lithic assemblage comprising both Middle and Late Aurignacian lithics. SU 17 is made up of yellow/brown silt-clay sediment with numerous small limestone fragments and contains a still difficult to characterise Aurignacian industry. SU 18 is approximately $20 \mathrm{~cm}$ thick and is composed of yellow / orange sandy-silty sediment with numerous small limestone fragments and decimetric blocks. The SU 18 lithic assemblage comprises a mix of Mousterian and Châtelperronian artefacts, which is consistent with a recent revision of material recovered by Lévêque from a broadly equivalent archaeological unit (EJOP upper; [19]). The lowermost SU 19 is a yellow/orange sandy/silty sediment with numerous, sometimes large limestone blocks that seals the underlying Mousterian (Lévêque's EGPF). This unit is about $20 \mathrm{~cm}$ thick and contains only a small quantity of bone and lithic artefacts.

\section{Material and Methods}

The micromammal sample analysed here comes from a succession of $2 \mathrm{~cm}$ spits excavated in sub-square J4 III (e.g., spit 176-178 cm, the datum point " 0 " being situated in the cliff above the stratigraphic sequence) (Figure 1B). This area of the site was selected because it corresponds to a zone where the SUs were the thickest, making it possible to follow a continuous series of spits down to the fallen stone blocks that mark the limit with the relatively sterile level separating the yellow upper sequence (EJ units) from the underlying grey Mousterian (EG units) levels (Figure 1C, and see [21] for more details). All sediments were recovered from successive $2 \mathrm{~cm}$ spits and subsequently water-sieved using 4 and $2 \mathrm{~mm}$ meshes after the sediment volume was estimated by litre (minus stones with a maximum dimension of $10 \mathrm{~cm}$ or more). The mesh size used to sieve the sediments is quite large for micromammal sampling, and this could have had an impact on the representation of some very small taxa (such as Sicista sp.) and small bone elements. Sub-square J4 III is divided into four subunits ( $a, b, c$ and $d)$, all corresponding to 16ths of a square metre. All objects greater than $2 \mathrm{~cm}$ (e.g., lithic, fauna) were piece-plotted in three dimensions with the help of a Total Station. We focused on micromammals, specifically rodents and insectivores, which form the bulk of the small vertebrate accumulation. Avifauna, herpetofauna, ichthyofauna, and lagomorpha are present but only in small proportions.

The taphonomic study of micromammals followed the standard methodology and data available in [6-10]. We focused primarily on the relative abundance, intensity and frequency of digestion marks. The relative abundance of skeletal elements was calculated using the formula provided by Dodson and Wexlar [24] and Andrews [7]:

$$
\mathrm{R} i=\mathrm{N} i /(\mathrm{MNI} \times \mathrm{E} i)
$$

where $\mathrm{R} i$ is the relative abundance of element $i$; $\mathrm{N} i$, the number of elements $i$ as measured by MNE (Minimum Number of Elements); MNI, the Minimum Number of Individuals; Ei, 
the number of the element $i$ in the skeleton. For our analysis, we considered the rodent skeleton to comprise two hemimaxillae; two hemimandibles; four incisors; 12 molars; two humeri; two radii; two ulnae; two femora; two tibiae; two scapulae; two innominates; two tali; two calcanei; 24 ribs; 54 vertebrae; 78 phalanges and metapodia.

Traces of digestion on bone surfaces result from the action of the gastric juices of the predator on the various bone elements. The frequency and intensity of these alterations allows different categories of predators to be identified. For example, nocturnal raptors produce less frequent and less intense bone surface alteration compared to diurnal raptors, and even fewer compared to small carnivores [6-10].

To quantify the micromammal accumulation, we used the MNE as well as the density of remains per litre of sediment (“MNE/L"). We performed a Pearson correlation test using the Past (version 4.06) software to explore whether the density of micromammal remains is negatively correlated with various indicators of human occupations, including the abundance of macrofaunal remains, particularly as they were previously shown to primarily reflect human activity $[20,25]$. More specifically, proxies considered to reflect human occupation include the number of piece-plotted faunal remains (greater than $2 \mathrm{~cm}$ as well as any remain considered identifiable in the field) and the number of lithic artefacts (for simplicity, we only used those that are greater than $2 \mathrm{~cm}$ ). We also included the same types of material from an adjacent sub-square metre, J4 IV, in order to increase the sample size of proxies for human activity, especially macrofaunal remains. In order to test whether variations result from post-depositional processes or excavation methods, non-piece plotted faunal remains and lithic artefacts recovered from the sieve residue were weighed and subsequently calculated in grams per litre.

\section{Results}

\subsection{Taxonomic Composition}

The micromammal accumulation is dominated by Microtus arvalis/agrestis and Lasiopodomys gregalis (Table 1). We also note the presence of Arvicola amphibius and Microtus oeconomus, including a few remains attributed to Spermophilus sp., Talpa sp. and Sorex sp. A single lower first molar of Lemmus / Myopus sp. was identified in SU 17. Relatively small differences in the taxonomic composition are evident between the SUs. Testing whether these differences reflect sampling error or other factors requires a larger sample of stratigraphic units (Table 1). In comparison with Marquet's data [22], our sample includes fewer remains of Lasiopodomys gregalis and higher numbers of Microtus arvalis/agrestis remains. In addition, our sample does not include remains of Sicista betulina. It is unclear whether these differences could be linked to the mesh size, reflect sampling bias, as Marquet's samples were fairly small, or spatial patterning in the distribution of different micromammal species (Figure 2A-E).

Table 1. Micromammal species diversity at La Roche-à-Pierrot for each stratigraphic unit (SU), expressed in MNI (Minimum Number of Individuals).

\begin{tabular}{|c|c|c|c|c|c|c|c|c|c|}
\hline Species/SU & 15-Humus & 15 & 16 & $16 / 17$ & 17 & 17/18 & 18 & $18 / 19$ & 19 \\
\hline $\begin{array}{l}\text { Microtus arvalis/agrestis } \\
\text { (Common/field vole) }\end{array}$ & 5 & 63 & 33 & 77 & 106 & 26 & 28 & 3 & 1 \\
\hline $\begin{array}{l}\text { Lasiopodomys gregalis } \\
\text { (Narrow-headed vole) }\end{array}$ & 7 & 74 & 40 & 42 & 109 & 32 & 30 & 4 & 2 \\
\hline $\begin{array}{l}\text { Arvicola amphibius } \\
\text { (European water vole) }\end{array}$ & 0 & 5 & 0 & 0 & 8 & 1 & 1 & 1 & 1 \\
\hline $\begin{array}{l}\text { Microtus oeconomus } \\
\text { (Root vole) }\end{array}$ & 0 & 4 & 0 & 0 & 2 & 0 & 1 & 0 & 0 \\
\hline $\begin{array}{l}\text { Lemmus/Myopus sp. } \\
\text { (Lemming) }\end{array}$ & 0 & 0 & 0 & 0 & 1 & 0 & 0 & 0 & 0 \\
\hline
\end{tabular}


Table 1. Cont

\begin{tabular}{cccccccccc}
\hline Species/SU & $\mathbf{1 5 - H u m u s}$ & $\mathbf{1 5}$ & $\mathbf{1 6}$ & $\mathbf{1 6 / 1 7}$ & $\mathbf{1 7}$ & $\mathbf{1 7 / 1 8}$ & $\mathbf{1 8}$ & $\mathbf{1 8 / 1 9}$ & $\mathbf{1 9}$ \\
\hline $\begin{array}{c}\text { Spermophilus sp. } \\
\text { (Ground squirrel) }\end{array}$ & 0 & 1 & 0 & 1 & 0 & 1 & 1 & 0 \\
\hline Sorex sp. (Shrew) & 0 & 1 & 0 & 1 & 0 & 0 & 1 & 0 \\
\hline Talpa sp. (Mole) & 0 & 0 & 0 & 0 & 0 & 0 & 1 & 0 \\
\hline
\end{tabular}

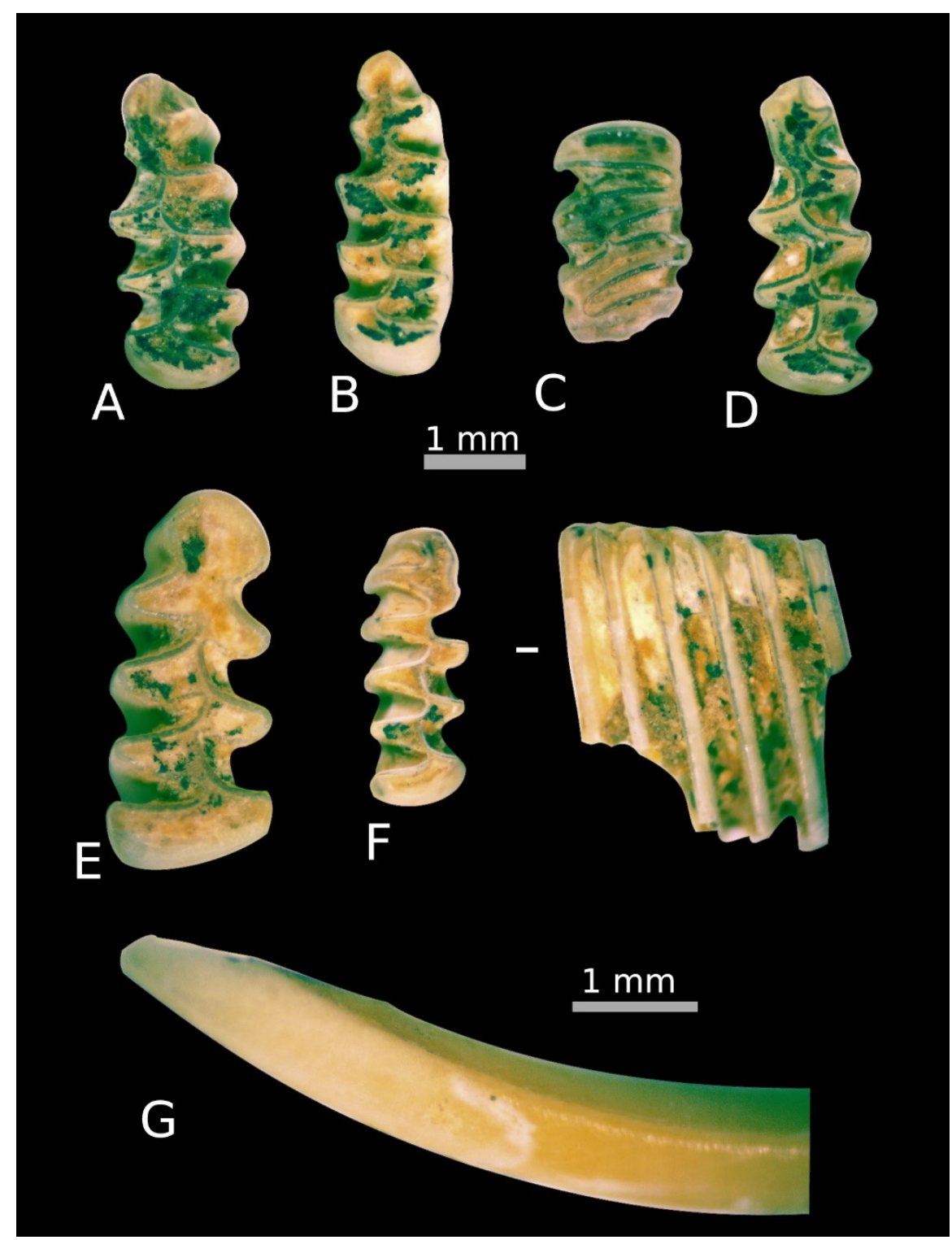

Figure 2. Rodent remains from La-Roche-à-Pierrot. (A) First lower molar (left) of Lasiopodomys gregalis; (B) first lower molar (left) of Microtus arvalis /agrestis; (C) third upper molar (right) of Lemmus / Myopus; (D) first lower molar (left) of Microtus oeconomus; (E) first lower molar (right) of Arvicola amphibius; (F) first lower molar (right) of Lasiopodomys gregalis with signs of moderate digestion (category 2), occlusal and lateral view; (G) rodent lower incisor (left) with signs of light digestion (category 1), characterised by the reduction of enamel on the tip (Table 2). 
Table 2. Number (N) and percentage (\%) of digested Arvicolinae teeth for each SU (Stratigraphic Unit), according to the intensity of the alteration defined by Andrews (1990): $0=$ null; $1=$ light; 2 = moderate; $3=$ strong.

\begin{tabular}{|c|c|c|c|c|c|c|c|c|c|c|c|c|c|c|c|c|c|c|}
\hline \multirow{3}{*}{ SU } & \multicolumn{9}{|c|}{ Incisors } & \multicolumn{9}{|c|}{ Molars } \\
\hline & \multicolumn{2}{|c|}{0} & \multicolumn{2}{|c|}{1} & \multicolumn{2}{|c|}{2} & \multicolumn{2}{|c|}{3} & \multirow{2}{*}{ N Total } & \multicolumn{2}{|c|}{0} & \multicolumn{2}{|c|}{1} & \multicolumn{2}{|c|}{2} & \multicolumn{2}{|c|}{3} & \multirow{2}{*}{ N Total } \\
\hline & $\mathbf{N}$ & $\%$ & $\mathbf{N}$ & $\%$ & $\mathbf{N}$ & $\%$ & $\mathbf{N}$ & $\%$ & & $\mathbf{N}$ & $\%$ & $\mathbf{N}$ & $\%$ & $\mathbf{N}$ & $\%$ & $\mathbf{N}$ & $\%$ & \\
\hline 15 & 82 & 92 & 5 & 6 & 2 & 2 & 0 & 0 & 89 & 62 & 97 & 1 & 2 & 0 & 0 & 1 & 2 & 64 \\
\hline 16 & 83 & 89 & 6 & 6 & 1 & 1 & 3 & 3 & 93 & 104 & 96 & 0 & 0 & 1 & 1 & 3 & 3 & 108 \\
\hline $16 / 17$ & 95 & 95 & 5 & 5 & 0 & 0 & 0 & 0 & 100 & 177 & 95 & 7 & 4 & 0 & 0 & 3 & 2 & 187 \\
\hline 17 & 251 & 93 & 18 & 7 & 0 & 0 & 0 & 0 & 269 & 374 & 95 & 12 & 3 & 5 & 1 & 3 & 1 & 394 \\
\hline $17 / 18$ & 66 & 94 & 4 & 6 & 0 & 0 & 0 & 0 & 70 & 92 & 95 & 4 & 4 & 0 & 0 & 1 & 1 & 97 \\
\hline 18 & 57 & 92 & 3 & 5 & 2 & 3 & 0 & 0 & 62 & 94 & 90 & 5 & 5 & 2 & 2 & 3 & 3 & 104 \\
\hline $18 / 19$ & 1 & - & 0 & - & 0 & - & 0 & - & 1 & 6 & - & 1 & - & 1 & - & 0 & - & 8 \\
\hline 19 & 0 & _ & 0 & _ & 0 & _ & 0 & _ & 0 & 2 & - & 1 & - & 2 & - & 0 & _ & 5 \\
\hline
\end{tabular}

\subsection{Origin of the Micromammal Accumulation}

Traces of digestion on Arvicolinae molars vary between $4 \%$ and $6 \%$ for SU $15-17$, and climb to $10 \%$ for SU 18, whereas for the incisors, evidence of digestion varies between $5 \%$ and $11 \%$. Most teeth exhibit low degrees of digestion, with only a limited number being heavily altered (Table 2). This low digestion rate and low intensity of digestion are consistent with a category 1 predator $[7,10]$, such as the barn owl (Tyto alba), short-eared (Asio flammeus) or long-eared owl (Asio otus). The presence of remains exhibiting moderate to extensive traces of alteration may highlight the limited contribution of another predator (less than $3 \%$ of digested teeth) such as diurnal raptors or small carnivores (Figure 2F,G).

All of the SUs are dominated by maxillae and mandibles followed by humeri, femora, incisors and molars. Small and fragile elements (ribs, phalanges, metapodia, vertebrae, radii) are consistently under-represented (Table S1, Figure 3), a pattern likely reflecting a similar post-depositional winnowing or destruction affecting all SUs equally.

\subsection{Density Variation}

The MNE/L ratio is very high at the top of the sequence (spits 147-150 to 168-170) and includes two density peaks: one at spit 150-152 and a second at spit 166-168 (Figure 4). This ratio is significantly lower towards the bottom of the sequence, except for a peak in spit 176-178. A similar increase in density is also observed between spits 186-188 and 190-192. Density variations observed between smaller subunits (16th of a square metre) are similar to those seen in sub-square J4 III as a whole. The small variations observed between these subunits occur at the interface between SU 17 and 18 and are most likely due to the fact that SU 18 was slightly higher in some places (as in J4 IIIb, spit 190-192 and J4 IIIc, spit 188-190). Additionally, the limited number of micromammal remains in SU 18 is reflected in small variations in specimen counts when SU 17 and 18 were recorded in the same spit during excavations.

The density measures and raw frequencies of micromammals used for the correlation test are provided in Table S2, while Table 3 provides the results of the Pearson correlation tests (Pearson's $r$ ) as well as associated $p$-values. A statistically significant positive correlation is observed between the density and MNE of micromammals, which is related to the small volume difference between spits. Proxies for human occupation (macrofauna and lithics) also show significant positive correlations between them. The significant positive correlation between piece-plotted lithic and faunal material and sieve residues supports variations in these variables reflecting human activity rather than excavation bias. 


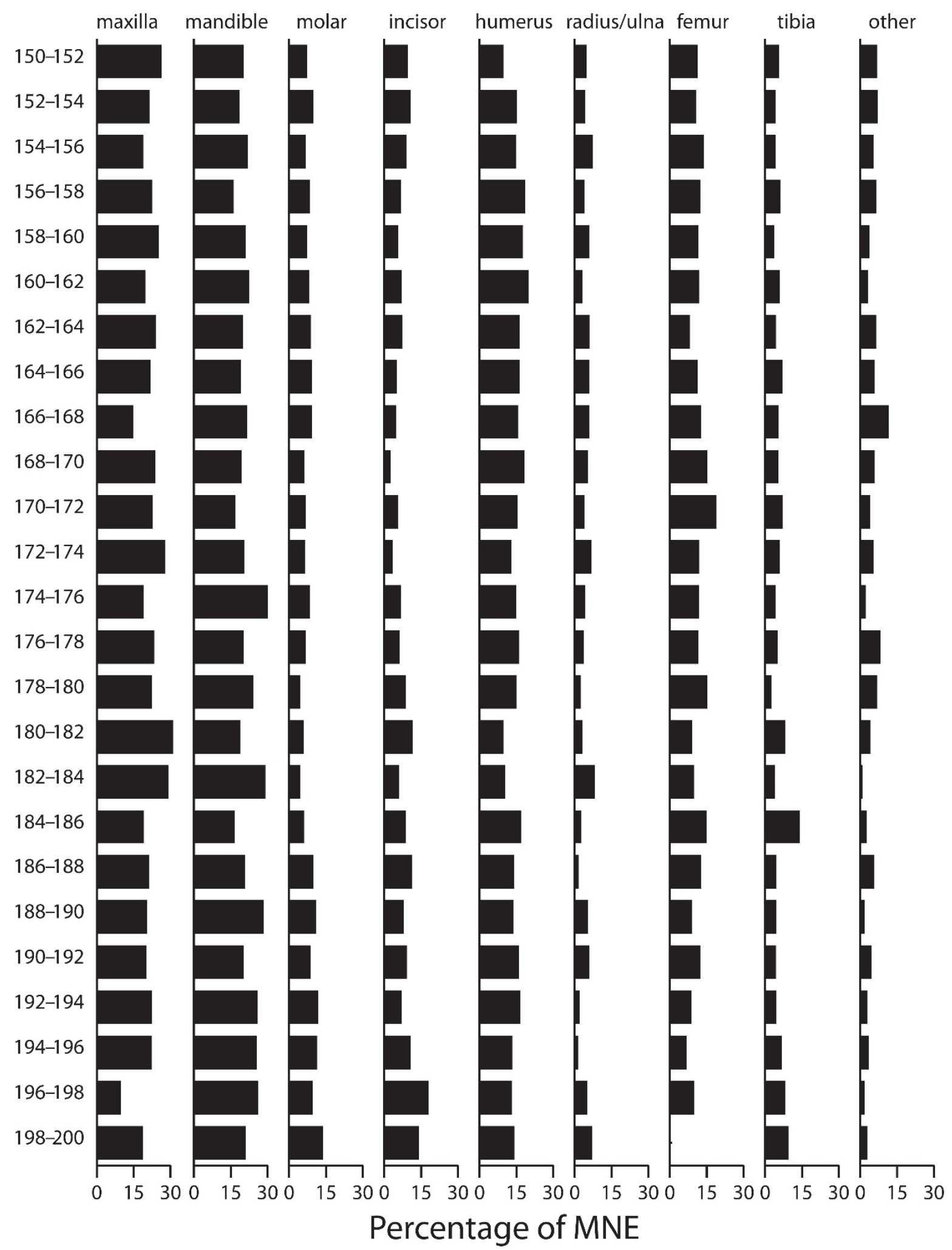

Figure 3. Skeletal part representation of micromammals by spit $(\mathrm{cm})$, expressed in percentage of MNE (Minimum Number of Elements). Spits 200-214 are not represented due to the small size of the samples. 


\begin{tabular}{|c|c|c|c|c|c|c|}
\hline SU & Spit & J4 IIla & J4 IIIb & J4 IIIC & J4 IIId & J4 III total \\
\hline 15-humus & 145-147 & & & & & 54 \\
\hline 15 & 147-150 & & & & & 135 \\
\hline 15 & $150-152$ & & & & & 183 \\
\hline 15 & 152-154 & & & & & 144 \\
\hline $15 / 16$ & 154-156 & & & & & 92 \\
\hline 16 & $156-158$ & 104 & 134 & 54 & 92 & 96 \\
\hline 16 & $158-160$ & 58 & 78 & 73 & 93 & 76 \\
\hline $16 / 17$ & $160-162$ & 40 & 55 & 118 & 42 & 64 \\
\hline $16 / 17$ & $162-164$ & 91 & 27 & 124 & 85 & 82 \\
\hline $16 / 17$ & $164-166$ & 116 & 77 & 119 & 70 & 95 \\
\hline 17 & $166-168$ & 145 & 101 & 126 & 91 & 102 \\
\hline 17 & $168-170$ & 111 & 72 & 60 & 65 & 77 \\
\hline 17 & $170-172$ & 78 & 26 & 68 & 27 & 50 \\
\hline 17 & $172-174$ & 27 & 34 & 39 & 22 & 30 \\
\hline 17 & 174-176 & 117 & 64 & 14 & 25 & 55 \\
\hline 17 & $176-178$ & 109 & 48 & 63 & 99 & 80 \\
\hline 17 & $178-180$ & 99 & 14 & 19 & 44 & 44 \\
\hline 17 & $180-182$ & 34 & 18 & 19 & 18 & 22 \\
\hline 17 & $182-184$ & 11 & 5 & 10 & 28 & 14 \\
\hline $17 / 18$ & $184-186$ & 10 & 13 & 10 & 30 & 16 \\
\hline $17 / 18$ & $186-188$ & 30 & 67 & 34 & 30 & 40 \\
\hline $17 / 18$ & $188-190$ & 13 & 24 & 8 & 56 & 25 \\
\hline $17 / 18$ & 190-192 & 49 & 2 & 69 & 95 & 54 \\
\hline 18 & 192-194 & 34 & 19 & 24 & 49 & 31 \\
\hline 18 & 194-196 & 13 & 15 & 20 & 24 & 18 \\
\hline 18 & 196-198 & 7 & 14 & 15 & 10 & 11 \\
\hline 18 & $198-200$ & 10 & 2 & 16 & 4 & 8 \\
\hline 18 & $200-202$ & 6 & & 10 & 14 & 10 \\
\hline 18 & $202-204$ & 16 & & 23 & 14 & 18 \\
\hline 18 & $204-206$ & 30 & & 6 & 21 & 19 \\
\hline 18 & $206-208$ & 2 & & 26 & 13 & 13 \\
\hline 18 & $208-210$ & 4 & & 8 & 19 & 10 \\
\hline 18 & $210-212$ & 9 & & 4 & 5 & 6 \\
\hline 19 & $212-214$ & 7 & & 9 & 6 & 7 \\
\hline
\end{tabular}

Figure 4. Density of micromammal remains (MNE/L) along the stratigraphic sequence of the quarter of a square metre J4 III and its smaller subdivisions (a, b, c, and d). Spits highlighted in orange correspond to maximum density peaks. SU: Stratigraphic Unit.

As expected, there is a negative correlation between micromammals (density and MNE micro) and the proxies for human occupation ( $\mathrm{N}$ fauna and $\mathrm{N}$ lithics). All relationships are statistically significant except for the comparison between lithics (J4 III) and the density of micromammals $(r=-0.303, p=0.09)$. The lack of statistical significance between these variables may be due to sampling bias, given the small number of lithic artefacts greater than $2 \mathrm{~cm}$ recovered from the limited surface area of J4 III. 
Table 3. Pearson's $r$ correlation coefficient (lower left part of the table) and associated $p$-values (upper right part of the table) for different variables along the spit sequence. Coefficient values in bold are associated with a significant $p$-value at the $5 \%$ threshold. Negative correlations in orange, positive correlations in green, the darker shades indicate stronger correlations. $\mathrm{N}$ = number of remains and $\mathrm{W}=$ weight of faunal remains and lithic artefacts recovered from the sieve residues (g/L). "Density" corresponds to the density of micromammal remains (MNE/L); "MNE micro" refers to micromammals and "fauna" to macrofauna.

\begin{tabular}{ccccccccc}
\hline & Density & MNE Micro & $\begin{array}{c}\text { N Fauna } \\
\text { J4 III }\end{array}$ & $\begin{array}{c}\text { N Fauna J4 } \\
\text { III-IV }\end{array}$ & $\begin{array}{c}\text { N Lithics } \\
\text { J4 III }\end{array}$ & $\begin{array}{c}\text { N Lithics } \\
\text { J4 III-IV }\end{array}$ & $\begin{array}{c}\text { W } \\
\text { Fauna }\end{array}$ & W Lithics \\
\hline Density & & $1.97 \times 10^{-10}$ & 0.681 & 0.040 & 0.091 & 0.002 & 0.604 & 0.717 \\
\hline MNE Micro & $\mathbf{0 . 8 6 4}$ & & 0.866 & 0.003 & 0.019 & $3.79 \times 10^{-5}$ & 0.234 & 0.095 \\
\hline N Fauna J4 III & 0.076 & 0.031 & & $8.55 \times 10^{-5}$ & 0.016 & 0.789 & 0.039 & 0.328 \\
\hline N Fauna J4 III-IV & $\mathbf{- 0 . 3 6 4}$ & $\mathbf{- 0 . 5 0 2}$ & $\mathbf{0 . 6 3 8}$ & & 0.001 & $3.62 \times 10^{-5}$ & 0.0002 & 0.002 \\
\hline N Lithics J4 III & -0.303 & $\mathbf{- 0 . 4 1 2}$ & $\mathbf{0 . 4 2 3}$ & $\mathbf{0 . 5 5 2}$ & & 0.001 & 0.017 & 0.088 \\
\hline N Lithics J4 III-IV & $\mathbf{- 0 . 5 2 1}$ & $\mathbf{- 0 . 6 6 1}$ & -0.049 & $\mathbf{0 . 6 6 2}$ & $\mathbf{0 . 5 5 6}$ & & 0.012 & 0.002 \\
\hline W Fauna & 0.095 & -0.216 & $\mathbf{0 . 3 6 6}$ & $\mathbf{0 . 6 2 1}$ & $\mathbf{0 . 4 1 7}$ & $\mathbf{0 . 4 4 1}$ & & $8.17 \times 10^{-13}$ \\
\hline W Lithics & 0.067 & -0.300 & 0.179 & $\mathbf{0 . 5 3 1}$ & $\mathbf{0 . 3 0 6}$ & $\mathbf{0 . 5 3 0}$ & $\mathbf{0 . 9 0 7}$ \\
\hline
\end{tabular}

\section{Discussion}

When compared with data presented by Andrews [7], the accumulation of small mammals at Saint-Césaire is consistent with the action of a category 1 nocturnal raptor. As short-eared (Asio otus) and long-eared owls (Asio flammeus) do not generally nest in karst contexts [26,27], the assemblage was most likely produced by a barn owl (Tyto alba). While this species has not been identified at the site, this does not exclude it from being responsible for the accumulation [7].

The overall accumulation shows a strong over-representation of $M$. arvalis/agrestis and L. gregalis, which may be related to the preferences of the main accumulating agent to hunt in open landscapes. As mentioned above, further work is necessary to identify the source of the variations in species frequencies recorded in the stratigraphic sequence. Patterns of skeletal representation do not reveal any major changes in the preservation of skeletal elements that seem to be due to post-depositional processes or shifts in the type of predators. The observed variations in density of micromammal remains therefore appear to be primarily linked to the activities of the accumulating agent rather than external factors, such as variations in micromammal palaeocommunities.

Given that the micromammal remains were most likely accumulated by a nocturnal bird of prey, it is reasonable to assume that phases of human occupation created unfavourable conditions for the presence of these birds at the site. The negative correlations between the proxies for human occupation and the micromammal variables (density measures) are consistent with this conclusion. The density peaks observed along the stratigraphic sequence could therefore correspond to more ephemeral phases of human occupation or periods when the site was abandoned. The high density of remains between depths $162-170$, with the density peak in the spit 166-168, could correspond to a period during which human occupations were less frequent or more ephemeral. This portion of the sequence corresponds to the transition between SU 17 (Indeterminate Aurignacian) and SU 16 (Middle/Late Aurignacian). Among the various peaks, the one observed in spit $176-178$ is considerably more marked and could correspond to the abandonment of the site by human groups. Moreover, this particular accumulation episode of micromammals within SU 17 distinguishes two portions of this SU 17 that were difficult to identify during fieldwork. The small peak in spit 190-192 coincides with the base of SU 17, which is markedly different from SU 18, which contains a limited number of small mammal remains. This abrupt shift in small mammal density between SU 17 and SU 18 may prove useful in future stratigraphic analyses. Our results confirm that the quantification of micromammal accumulations can be a useful proxy for better documenting stratigraphic sequences, 
whereas accumulation peaks can provide evidence for phases of site abandonment. Tracking shifts in micromammal densities therefore represents a new complementary tool for characterising the frequency and timing of human occupations at archaeological sites which commonly rely uniquely on macrofauna and lithics. Moreover, with the development of ancient DNA recovered from sediments [28,29], this type of analysis can aid in identifying sampling areas most likely to preserve human DNA.

Our results may be difficult to place in a broader perspective as similar analyses are still rare for Palaeolithic contexts. Nonetheless, they indicate that due consideration should be paid to recovery methods employed during excavations. Among other factors, clast content and sediment volume are particularly critical, as both may produce biases in artefact density estimates. These problems may partly be controlled for by precisely measuring spit volumes or recording spits of constant volume.

\section{Conclusions}

At Saint-Césaire, higher densities of micromammal remains seem to coincide with phases of limited human occupation whereas lower densities appear to denote periods when the site was only sporadically occupied or abandoned. In the upper part of the archaeological sequence, four accumulation peaks provide new data for (a) securely assigning spits to particular stratigraphic units in inter-unit transitional zones, and (b) identifying different occupation phases within the same stratigraphic unit.

Shifts in micromammal densities may not always produce reliable results due to the impact of post-depositional processes that remobilised archaeological material and/or geochemical alterations that locally affected faunal preservation. Despite these issues, micromammal proxies have considerable potential for documenting changes in patterns of human occupation, particularly if they are coupled with standard taphonomic analyses of microfaunal and macrofaunal remains and when these data are assessed in light of dynamic site formation processes and estimated sedimentation rates. In sum, the development of micromammal analyses should contribute to a more reliable interpretation of archaeological sites as well as the timing and frequency of human occupations.

Supplementary Materials: The following are available online at https: / www.mdpi.com/article / 10.3390/quat4040033/s1, Table S1: Micromammal MNE (Minimum Number of Elements) for each spit and SU, Table S2: Variables taken into account for the correlation test along the spit sequence. $\mathrm{N}=$ Number of remains and $\mathrm{W}=$ weight of faunal remains and lithic artefacts recovered from the sieve residues $(\mathrm{g} / \mathrm{L})$.

Author Contributions: Conceptualisation, L.L. and E.M.; data curation, L.L., E.M., B.G., A.M., F.B., D.F., J.M., H.R. and I.C.; formal analysis, L.L.; methodology, L.L. and E.M.; supervision, I.C.; writing—original draft, L.L.; writing—review and editing, E.M., B.G., C.B., V.L., H.R., E.T., D.T. and I.C. All authors have read and agreed to the published version of the manuscript.

Funding: This research received no external funding.

Institutional Review Board Statement: Not applicable.

Informed Consent Statement: Not applicable.

Data Availability Statement: The data presented in this study are available in this paper.

Acknowledgments: We thank the Service régional de l'Archéologie (SRA) Nouvelle-Aquitaine, the Service départemental de l'Archéologie (SDA) of Charente-Maritime and the Conseil départemental of CharenteMaritime for their financial support to the Projet Collectif de Recherche (PCR) La Roche-à-Pierrot directed by I.C. We also want to thank the two anonymous reviewers for their suggestions and comments that improved the final version of the manuscript.

Conflicts of Interest: The authors declare no conflict of interest. 


\section{References}

1. Royer, A.; Lécuyer, C.; Montuire, S.; Escarguel, G.; Fourel, F.; Mann, A.; Maureille, B. Late Pleistocene (MIS 3-4) climate inferred from micromammal communities and $\delta^{18} \mathrm{O}$ of rodents from Les Pradelles, France. Quat. Res. 2013, 80, 113-124. [CrossRef]

2. Lebreton, L.; Desclaux, E.; Hanquet, C.; Moigne, A.-M.; Perrenoud, C. Environmental context of the Caune de l'Arago Acheulean occupations (Tautavel, France), new insights from microvertebrates in Q-R levels. Quat. Int. 2016, 411, 182-192. [CrossRef]

3. Stoetzel, E.; Montuire, S. Les rongeurs, indicateurs des paléoclimats: Application aux assemblages de trois sites du nord de la France. Quaternaire 2016, 27, 227-238. [CrossRef]

4. López-García, J.M.; Blain, H.A.; Sánchez-Bandera, C.; Cohen, J.; Lebreton, L.; Montuire, S.; Stewart, J.R.; Desclaux, E. Multimethod approach using small vertebrate assemblages to reconstruct the Marine Isotope Stage 6 climate and environment of the Lazaret cave sequence (Maritime Alps, Nice, France). Palaeogeogr. Palaeoclimatol. Palaeoecol. 2021, 577, 110529. [CrossRef]

5. Piñero, P.; Agustí, J.; Blain, H.A.; Laplana, C. Paleoenvironmental reconstruction of the Early Pleistocene site of Quibas (SE Spain) using a rodent assemblage. C. R. Palevol 2016, 15, 659-668. [CrossRef]

6. Denys, C. Nouveaux critères de reconnaissance des concentrations de microvertébrés d'après l'étude des pelotes de chouettes du Botswana (Afrique australe). Bulletin du Muséum National d'Histoire Naturelle 1985, 7, 879-933.

7. Andrews, P. Owls, Caves and Fossils: Predation, Preservation, and Accumulation of Small Mammal Bones in Caves, with an Analysis of the Pleistocene Cave Faunas from Westbury-Sub-Mendip; University of Chicago Press: Somerset, UK, 1990; 231p.

8. Fernández-Jalvo, Y.; Andrews, P. Small Mammal Taphonomy of Gran Dolina, Atapuerca (Burgos), Spain. J. Archaeol. Sci. 1992, 19, 407-428. [CrossRef]

9. Fernández-Jalvo, Y.; Denys, C.; Andrews, P.; Williams, T.W.; Dauphin, Y.; Humphrey, L. Taphonomy and palaeoecology of Olduvai Bed-I (Pleistocene, Tanzania). J. Hum. Evol. 1998, 34, 137-172. [CrossRef] [PubMed]

10. Fernández-Jalvo, Y.; Andrews, P.; Denys, C.; Sese, C.; Stoetzel, E.; Marin Monfort, D.; Pequero, D. Taphonomy for taxonomists, implications in small mammal studies. Quat. Sci. Rev. 2016, 139, 138-157. [CrossRef]

11. Denys, C. Des référentiels en taphonomie des petits vertébrés: Bilan et perspectives. In Taphonomie des Petits Vertébrés: Référentiels et Transferts Aux Fossiles; Laroulandie, V., Mallye, J.-B., Denys, C., Eds.; British Archaeological Reports; International Series 2269; Archaeopress: Oxford, UK, 2011; pp. 7-22.

12. Rofes, J.; Ordiales, A.; Iriarte, E.; Cuenca-Bescós, G.; Galindo-Pellicena, M.Á.; Pérez-Romero, A.; Carretero, J.M.; Arsuaga, J.L. Human Activities, Biostratigraphy and Past Environment Revealed by Small-Mammal Associations at the Chalcolithic Levels of El Portalón de Cueva Mayor (Atapuerca, Spain). Quaternary 2021, 4, 16. [CrossRef]

13. Royer, A. Intérêts de l'utilisation des décapages lors des fouilles archéologiques pour l'étude des restes de petits vertébrés. PALEO 2014, 25, 277-286. [CrossRef]

14. Laroulandie, V.; Royer, A.; Mallye, J.-B.; Bailon, S.; Danger, M. Les petits vertébrés de Peyrazet et les chasseurs-collecteurs du Magdalénien supérieur. In La Grotte-Abri de Peyrazet (Creysse, Lot, France) au Magdalénien. Originalité fonctionnelle d'un Habitat des Derniers Chasseurs de Rennes du Quercy; Langlais, M., Laroulandie, V., Eds.; Supplément à Gallia Préhistoire 43; CNRS: Paris, France, 2021; pp. 141-152.

15. Rambaud, D.; Laroulandie, V.; Primault, J.; Béarez, P. Les poissons et les oiseaux du Taillis des Coteaux (Antigny, Vienne), niveaux magdaléniens: Origine naturelle ou culturelle? In Taphonomie des Petits Vertébrés: Référentiels et Transferts Aux Fossiles; Laroulandie, V., Mallye, J.-B., Denys, C., Eds.; British Archaeological Reports; International Series 2269; Archaeopress: Oxford, UK, 2011; pp. 167-179.

16. Richardson, C.; Miller, C. Recommendations for Protecting Raptors from Human Disturbance: A Review. Wildl. Soc. Bull. (1973-2006) 1997, 25, 634-638.

17. Martínez-Abraín, A.; Oro, D.; Jiménez, J.; Stewart, G.; Pullin, A. A systematic review of the effects of recreational activities on nesting birds of prey. Basic Appl. Ecol. 2010, 11, 312-319. [CrossRef]

18. Lévêque, F.; Vandermeersch, B. Découverte de restes humains dans un niveau castelperronien à Saint-Césaire (Charente-Maritime). C. R. l'Acad. Sci. Paris Sér. D 1980, 291, 187-189.

19. Gravina, B.; Bachellerie, F.; Caux, S.; Discamps, E.; Faivre, J.-P.; Galland, A.; Michel, A.; Teyssandier, N.; Bordes, J.-G. No reliable evidence for a Neanderthal-Châtelperronian association at La Roche-à-Pierrot, Saint-Césaire. Sci. Rep. 2018, 8, 15134. [CrossRef] [PubMed]

20. Morin, E. Reassessing Paleolithic Subsistence: The Neandertal and Modern Human Foragers of Saint-Césaire; Cambridge University Press: New York, NY, USA, 2012; 358p.

21. Lévêque, F.; Backer, A.M.; Guilbaud, M. (Eds.) Context of a Late Neandertal. Implications of Multidisciplinary Research for the Transition to Upper Paleolithic Adaptations at Saint-Césaire, Charente-Maritime, France; Monographs in World Archaeology 16; Prehistory Press: Madison, WI, USA, 1993; 131p.

22. Marquet, J.-C. Paléoenvironnement et Chronologie des Sites du Domaine Atlantique Français d'âge Pléistocène Moyen et Supérieur D'après L'étude des Rongeurs; Les Cahiers de la Claise, Supplément 2: Tours, France, 1993; 330p.

23. Crevecoeur, I. Reprise des fouilles à La Roche-à-Pierrot, Saint-Césaire. In Le troisième Homme. Préhistoire de l'Altä̈; Cleyet-Merle, J.-J., Derevianko, A.P., Geneste, J.-M., Gravina, B., Krivoshapkin, A.I., Maureille, B., Turq, A., Shunkov, M.V., Slimak, L., Eds.; Réunion des Musées Nationaux-Grand Palais: Paris, France, 2017; p. 107.

24. Dodson, P.; Wexlar, D. Taphonomic investigations of owl pellets. Paleobiology 1979, 5, 275-284. [CrossRef] 
25. Morin, E. Evidence for declines in human population densities during the early Upper Paleolithic in western Europe. Proc. Natl. Acad. Sci. USA 2008, 105, 48-53. [CrossRef]

26. Roberts, J.L.; Bowman, N. Diet and ecology of Short-eared Owls Asio flammeus breeding on heather moor. Bird Study 1986, 33, 12-17. [CrossRef]

27. Martínez, J.A.; Zuberogoitia, I. Habitat preferences for Long-eared Owls Asio otus and Little Owls Athene noctua in semi-arid environments at three spatial scales. Bird Study 2004, 51, 163-169. [CrossRef]

28. Slon, V.; Hopfe, C.; Weiß, C.L.; Mafessoni, F.; de la Rasilla, M.; Lalueza-Fox, C.; Rosas, A.; Soressi, M.; Knul, M.V.; Miller, R.; et al. Neandertal and Denisovan DNA from Pleistocene sediments. Science 2017, 356, 605-608. [CrossRef]

29. Rohland, N.; Glocke, I.; Aximu-Petri, A.; Meyer, M. Extraction of highly degraded DNA from ancient bones, teeth and sediments for high-throughput sequencing. Nat. Protoc. 2018, 13, 2447-2461. [CrossRef] [PubMed] 